\title{
Intravenous Immune Globulin for the Prevention of Infections in Children with Symptomatic Human Immunodeficiency Virus Infection"
}

\author{
LYNNE M. MOFENSON AND JOHN MOYE, JR. \\ Pediatric, Adolescent and Maternal AIDS Branch, National Institute of Child Health and Human Development, \\ National Institutes of Health, Bethesda, Maryland 20852
}

\begin{abstract}
Infection with human immunodeficiency virus (HIV) causes a progressive immunodeficiency, often manifested in adults by the development of infections with relatively rare, opportunistic organisms. However, in HIVinfected children, recurrent serious infections with common encapsulated bacteria, as well as recurrent minor bacterial and viral infections, may be early and frequent manifestations of HIV disease. The use of i.v. immune globulin (IVIG) has been shown to prevent infections in patients with primary immunodeficiency and in uncontrolled studies of HIV-infected children. This article reviews the problem of and immunologic predisposition for recurrent infections in pediatric HIV infection and reports on the use of IVIG for prophylaxis. Updated analysis from the National Institute of Child Health and Human Development IVIG Clinical Trial, a multicenter, double-blind, placebo-controlled trial of the safety and efficacy of IVIG for the prevention of infections in children with symptomatic HIV infection, is presented. Between March 1988 and January 1991, 376 children with clinical or immunologic evidence of HIV disease who were randomized to receive IVIG or albumin placebo were enrolled in this trial. In children with an entry CD4+ count of $200 / \mathrm{mm}^{3}$ or higher, IVIG significantly increased the time free from serious bacterial infections and significantly decreased the rates of minor bacterial infections and viral infections. (Pediatr Res 33 (Suppl): S80-S89, 1993)
\end{abstract}

\section{Abbreviations}

HIV, human immunodeficiency virus

IVIG, intravenous immune globulin

NICHD, National Institute of Child Health \& Human Development

PCP, Pneumocytis carinii pneumonia

ZDV, zidovudine

CDC, Centers for Disease Control

ACTG, AIDS Clinical Trial Group

Infection with HIV is characterized by a progressive immunologic deficiency manifested by depletion of CD4+ helper lymphocytes, resulting in opportunistic infections and a severe deficit in cellular immunity. Additionally, alterations in B-lymphocyte function are common, resulting in deficits in the hu-

Correspondence: Lynne M. Mofenson, M.D., Associate Branch Chief for Clinical Research, Pediatric, Adolescent \& Maternal AIDS Branch, National Institute of Child Health \& Human Development, National Institutes of Health, 6100 Executive Blvd., Room 4B11, Rockville, MD 20852.

Portions of this article were modified from Mofenson LM, Shearer WT 1992 Use of IVIG in pediatric HIV infection. Semin Pediatr Infect Dis 3:1-10. moral arm of the immune system (1). Such B-cell abnormalities appear to be multifactorial in origin, with demonstration of both intrinsic B-cell defects and defects secondary to CD4+ helper dysfunction (1-4). Functional abnormalities of B lymphocytes noted in vitro include elevated spontaneous proliferation, increased numbers of spontaneous plaque-forming cells in the peripheral blood, enhanced responsiveness to B-cell growth factors, and refractoriness to normal in vitro signals for B-cell activation (1). In vivo manifestations of dysfunction include hypergammaglobulinemia, circulating immune complexes, an inability to mount an appropriate serologic response after immunization, and an increased frequency of common bacterial and viral infections.

Although B- and T-cell dysfunction are seen in both HIVinfected adults and children, the consequences of B-cell dysfunction may be more pronounced in children, particularly those with vertically acquired infection. In adults, even if response to new antigens is diminished, preexisting memory cells provide some immunity from infection with common pathogens. However, if defective B-cell function occurs early in life, before the development of specific memory cells, recurrent and severe infection with otherwise common organisms may result.

In children with HIV infection, recurrent infection with common bacterial and viral organisms is a frequent and early manifestation of HIV disease. The similarity of the type of infections seen in HIV-infected children to those seen in children with congenital hypogammaglobulinemia provided the early rationale for use of IVIG for infection prophylaxis in pediatric HIV infection. This article briefly reviews the problem of and the immunologic predisposition for recurrent infections in HIVinfected children and summarizes the published reports on the use of IVIG for infection prophylaxis, including updated and newly analyzed data from the NICHD IVIG Clinical Trial. Although the focus of this article is on the use of IVIG for preexposure prophylaxis of infections, other current and potential uses for IVIG in pediatric HIV infection include treatment of HIV-associated thrombocytopenia, treatment of cytomegalovirus and Parvovirus B19 infection, and the potential use of hyperimmune HIV immune globulin for treatment of HIV infection and prevention of vertical transmission $(5,6)$.

\section{RECURRENT INFECTIONS IN HIV-INFECTED CHILDREN}

HIV infection in adults is associated with the development of infections with relatively rare, opportunistic organisms. In contrast, the development of recurrent serious systemic illness caused by common encapsulated bacteria is so common in HIV-infected children that the federal CDC modified the pediatric AIDS case definition in 1987 to include recurrent serious bacterial infections as an AIDS-indicator disease (7). Although PCP is the most frequent AIDS-defining illness in children, recurrent serious bacterial infections occurred in almost $25 \%$ of children with 
vertically acquired AIDS reported to the CDC between 1988 and 1989 (8). Additionally, chronic lung disease due to lymphoid interstitial pneumonitis was the presenting illness in $28 \%$; lymphoid interstitial pneumonitis can predispose to recurrent episodes of pneumonia, similar to other chronic pulmonary conditions.

Initial characterization of the problem of recurrent bacterial infections in HIV-infected children came from two retrospective studies from New York City $(9,10)$. In 1985, Bernstein et al. (9) reported that $57 \%$ of 46 children with AIDS or AIDS-related complex followed in their clinic experienced serious laboratoryproven or clinically diagnosed bacterial infections. Three y later, Krasinski et al. (10) reported that in their clinic population of 71 somewhat-less-symptomatic children $38 \%$ experienced a laboratory-proven serious bacterial infection over a 3.5-y period of observation. Recurrent infections were common in both cohorts. Septicemia accounted for the majority of infections; Streptococcus pneumoniae was the most commonly isolated organism (accounting for 27 and $31 \%$ of septicemic episodes in the 1985 and 1988 studies, respectively). Other gram-positive organisms included Staphylococcus aureus, Staphylococcus epidermidis, and viridans streptococci. Gram-negative organisms, particularly Salmonella, enteric bacteria, and Pseudomonas aeruginosa, also occurred in a significant proportion of children. Respiratory tract infections (particularly pneumonia), urinary tract infections, and skin/soft tissue infections were also common.

An elevated frequency of invasive pneumococcal disease in HIV-infected children has been noted in several other studies. A recent paper by Roilides et al. (11) noted that $61 \%$ of 105 patients followed over a 3-y period at the National Cancer Institute experienced bacterial infections. Bacteremia was the most common serious bacterial infection observed; $S$. pneumoniae was the most frequent cause of bacteremia, accounting for $20 \%$ of bacteremic episodes overall and $67 \%$ of bacteremic episodes in children without central venous catheters. A statewide population-based prospective study of HIV-infected children in Massachusetts has provided an estimate of the incidence of pneumococcal bacteremia in HIV-infected children, reporting an annualized rate of 6.7 episodes per 100 patient-years in their cohort (12). This rate is twice that observed in children under 6 y old with sickle cell anemia (3.2 per 100 patient-years) (13) and 7 times that reported from San Francisco in adults with AIDS (0.9 per 100 patient-years) (14).

Recurrent episodes of pneumonia also cause significant morbidity in HIV-infected children. Pneumonia was the second most frequent serious bacterial infection noted in the Bernstein and Krasinski reports and the third most common infection reported by Roilides and colleagues (9-11). In a retrospective chart review of 66 children with AIDS followed over a 6-y period in two New York City hospital clinics, Marolda et al. (15) noted that $79 \%$ of their cohort developed pulmonary problems, with $30 \%$ experiencing one or more episodes of laboratory-proven bacterial pneumonia and $70 \%$ having hospital admissions for an acute respiratory illness without an identified pathogen. In a small prospectively followed Italian cohort of $27 \mathrm{HIV}$-infected children and matched, uninfected controls, HIV-infected children had significantly more episodes of acute pneumonia per patient-year than did uninfected control patients (16).

Recurrent minor bacterial infections such as otitis media are also common in HIV-infected children. In the Italian cohort discussed above, although the number of children diagnosed with acute otitis media was similar between the HIV-infected and uninfected control groups, the HIV-infected children experienced significantly more episodes of otitis (17). Intriguingly, CD4+ lymphocyte counts and CD4+/CD8+ ratios were not significantly different between HIV-infected children with or without otitis episodes, suggesting that a more subtle immune deficit, occurring before CD4+ cell depletion, may predispose the children to recurrent bacterial infections.

\section{IMMUNOLOGIC PREDISPOSITION TO INFECTIONS IN PEDIATRIC HIV INFECTION}

As shown in Figure 1, the immunologic consequences of HIV infection differ between adults and young children (18). In older children and adults with HIV infection, lymphopenia and CD4+ cell depletion is characteristic and common. However, in young infants, who have a physiologic lymphocytosis early in life, CD4+ lymphopenia may not be observed despite the occurrence of severe HIV-related complications, such as PCP (19-21). Recently, age-related normal values for CD4+ lymphocytes were published $(21,22)$. In infants under 12 mo of age, a CD4+ count of $1500 / \mathrm{mm}^{3}$ or lower is more than $2 \mathrm{SD}$ below the mean, whereas in adults the corresponding CD4+ value is $500 / \mathrm{mm}^{3}$ or lower.

B-cell dysfunction occurs early in the course of HIV infection in children. Significant polyclonal hypergammaglobulinemia is noted frequently in HIV-infected infants and may be the earliest laboratory immunologic manifestation of HIV in infancy (23, 24). Similar to other dysfunctional hypergammaglobulinopathies, such as multiple myeloma, such children behave clinically as if they were functionally hypogammaglobulinemic, with a predisposition to infection with encapsulated bacteria and decreased antibody response to bacterial antigen $(4,25,26)$.

A sequential loss in $\mathrm{T}$-helper lymphocyte function before CD4+ cell decline has been described in both HIV-infected adults and children (27-29). In studies evaluating T-helper cell function by measuring $\mathrm{T}$-cell proliferation and IL-2 production in response to different types of antigenic stimuli, a progressive loss of response was noted, with loss to recall antigen stimulus being the earliest defect observed, followed by loss of response to alloantigen and finally mitogen stimulus.

These more subtle and progressive defects in T-helper cell function have been correlated with the slope of CD4+ cell decline over time (28) and with risk for infection. In a study of 34 children with HIV infection, a CD4+ count of $<200 / \mathrm{mm}^{3}$ was significantly associated with loss of response to all antigenic stimuli, whereas those children with no defects were more likely to have CD4+ counts of $>200 / \mathrm{mm}^{3}(p<0.02)$ (29). Additionally, the stage of $T$-helper cell functional deficit correlated with risk for infection. Infections were infrequent in those children with no functional defects. Loss of recall antigen alone was significantly associated with the occurrence of bacterial infections $(p<0.001)$; however, the risk of opportunistic infections was not significantly increased until all T-helper function was lost. The earliest immunologic manifestation of HIV infection, selec-

\begin{tabular}{|c|c|c|c|}
\hline$\frac{\text { ABNORMALITY }}{\text { Lymphopenia }}$ & $\begin{array}{l}\text { INFANT } \\
\qquad 1 \text { YR } \\
-\end{array}$ & $\begin{array}{l}\text { CHILDREN } \\
\frac{1-13 \text { YR }}{++}\end{array}$ & $\begin{array}{l}\text { ADOLESCENTS } \\
\frac{\text { ADULTS }}{+++}\end{array}$ \\
\hline CD4 Depletion & - & ++ & +++ \\
\hline Hypergammaglobulemia & +++ & +++ & ++ \\
\hline $\begin{array}{l}\text { Decreased Antibody } \\
\text { Response to Bacterial } \\
\text { Antigen }\end{array}$ & ++ & ++ & + \\
\hline Cutaneous Anergy & NA & ++ & ++ \\
\hline $\begin{array}{l}\text { Decreased Mitogen } \\
\text { Response (PHA<PWM) }\end{array}$ & + & ++ & ++ \\
\hline $\begin{array}{l}\text { Decreased Antigen } \\
\text { Response (Tetanus) }\end{array}$ & ++ & ++ & ++ \\
\hline
\end{tabular}

Fig. 1. Age-related differences in HIV-related immunologic abnormalities. PHA, phytohemagglutinin; $P W M$, pokeweed mitogen. Modified from: Stiehm ER, Wara DW 1991 Immunology of HIV. In: Pizzo PA, Wilfert CM (eds). Pediatric AIDS: The Challenge of HIV Infection in Infants, Children and Adolescents. Williams \& Wilkins, Baltimore, pp 95-112. 
tive loss of $T$-helper response to recall antigen stimulus, therefore appears to be associated with an increased risk of bacterial infections, whereas more progressive $T$-helper dysfunction appears to occur later in the course of HIV infection and to be associated with a decline in CD4+ cell number and the occurrence of opportunistic infections.

The relatively early occurrence of recurrent bacterial infections in pediatric HIV infection, before severe CD4+ depletion (by adult standards) occurs, can therefore be potentially explained by a combination of several factors, including the higher agespecific CD4+ count norms in young children, the early B-cell abnormalities and dysfunctional hypergammaglobulinemia observed in infected infants, and the early loss of $\mathrm{T}$-helper recall antigen response in immunologically naive HIV-infected infants.

\section{IVIG PROPHYLAXIS OF INFECTIONS IN HIV-INFECTED CHILDREN}

The rationale for IVIG prophylaxis in HIV-infected children is based upon the clinical similarity of the type and frequency of infections in HIV-infected children to those seen in children with congenital humoral immunodeficiencies and the successful use of IVIG to prevent infections in these congenital disorders (30).

In the latter half of the 1980 s, several investigators published reports indicating the potential benefit of IVIG for the prevention of infections in HIV-infected children. As summarized in Table 1 , there have been six published case reports, involving 61 patients, and three comparative reports, involving 51 treated patients (31-39). With the exception of one small comparative study conducted in an older hemophiliac population (39), which did not show a benefit of IVIG on infection prevention, the studies reported a variety of benefits with IVIG therapy, including decreased infections and hospitalizations, improvements in growth and survival, a decline in p24 antigen, and improvements in some immunologic abnormalities such as declines in elevated lactate dehydrogenase levels and improvements in suppressor cell function, mitogen response, and CD4+ cell count.

However, interpretation of these reports was difficult, due to the uncontrolled nature of most of the studies, the inadequate sample size in the studies, the widely varying regimens of IVIG used, the lack of standardized patient evaluation and follow-up, and the use of some product produced before 1985 that potentially contained antibody to HIV. Therefore, the National Institutes of Health sponsored two randomized, controlled, blinded clinical trials to examine the efficacy of IVIG for infection prophylaxis in HIV-infected children. One study (the NICHD IVIG Clinical Trial) has been completed (40) and the other (ACTG 051) remains ongoing.

\section{NICHD IVIG CLINICAL TRIAL}

Methods. The NICHD IVIG trial was a multicenter, doubleblind, placebo-controlled study to determine whether IVIG, in a dose of $400 \mathrm{mg} / \mathrm{kg}$ every $28 \mathrm{~d}$, would reduce the risk of serious bacterial infection or death in HIV-infected children. Figure 2 provides an overview of the protocol design. Nonhemophiliac,

Table 1. Summary of studies of IVIG prophylaxis in HIV-infected children*

\begin{tabular}{|c|c|c|c|c|}
\hline Author (reference) & $\begin{array}{c}\text { No. of } \\
\text { patients }\end{array}$ & $\begin{array}{l}\text { Type of } \\
\text { report }\end{array}$ & IVIG dose & Reported results \\
\hline Silverman et al. (31) & 33 & Case & $\begin{array}{r}\text { 3-wk escalation; } 300 \\
\mathrm{mg} / \mathrm{kg} \text { every } 2 \text { wk }\end{array}$ & $\mathrm{LDH} \dagger$ decline \\
\hline Gupta et al. (32) & 7 & Case & $\begin{array}{r}1 \text {-wk escalation; } 200 \\
\mathrm{mg} / \mathrm{kg} \text { every } 2 \mathrm{wk}\end{array}$ & $\begin{array}{l}\text { Suppressor cell function } \\
\text { improvement }\end{array}$ \\
\hline Wood et al. (33) & 1 & Case & $\begin{array}{l}400 \mathrm{mg} / \mathrm{kg} \text { loading; } \\
300 \mathrm{mg} / \mathrm{kg} \text { every } \\
\mathrm{mo}\end{array}$ & $\begin{array}{l}\text { No bacterial infections } \\
\text { over } 19 \text { mo }\end{array}$ \\
\hline Schaad et al. (34) & 7 & Case & $\begin{array}{l}\text { 3-mo escalation; } 400 \\
\mathrm{mg} / \mathrm{kg} \text { every mo }\end{array}$ & $\begin{array}{l}\text { Less febrile episodes } \\
\text { and infections; LDH } \\
\text { decline; normalized } \\
\text { growth and psycho- } \\
\text { motor development; } \\
\text { no deaths }\end{array}$ \\
\hline Williams et al. (35) & 5 & Case & $\begin{array}{l}\text { 2-wk escalation; } 200 \\
\mathrm{mg} / \mathrm{kg} \text { every 3-4 } \\
\text { wk }\end{array}$ & $\begin{array}{l}\text { Less severe infections; } \\
\text { reduced hospitaliza- } \\
\text { tion length; weight } \\
\text { gain }\end{array}$ \\
\hline Hague et al. (36) & 8 & Case & $200 \mathrm{mg} / \mathrm{kg}$ every $3 \mathrm{wk}$ & $\begin{array}{l}\text { Less infections; less hos- } \\
\text { pital days; weight } \\
\text { gain; decreases in p24 } \\
\text { antigen }\end{array}$ \\
\hline Calvelli et al. (37) & $\begin{array}{l}14 \text { treated } \\
27 \text { untreated }\end{array}$ & Comparative & $300 \mathrm{mg} / \mathrm{kg}$ every $2 \mathrm{wk}$ & $\begin{array}{l}\text { Decrease in sepsis and } \\
\text { febrile episodes; in- } \\
\text { crease in CD4+ } \\
\text { count; decrease in } \\
\text { immune complexes; } \\
\text { increased mitogenic } \\
\text { responses; LDH de- } \\
\text { cline }\end{array}$ \\
\hline Siegal and Oleske (38) & $\begin{array}{l}19 \text { treated } \\
12 \text { untreated }\end{array}$ & $\begin{array}{l}\text { Comparative, } \\
\text { unblinded }\end{array}$ & $100 \mathrm{mg} / \mathrm{kg}$ every week & Enhanced survival \\
\hline Wagner et al. (39) & $\begin{array}{l}18 \text { treated } \\
18 \text { untreated }\end{array}$ & $\begin{array}{l}\text { Comparative, } \\
\text { unblinded }\end{array}$ & $\begin{array}{l}400 \mathrm{mg} / \mathrm{kg} \times 5 \mathrm{~d} ; \\
300 \mathrm{mg} / \mathrm{kg} \text { every } 2 \mathrm{wk}\end{array}$ & $\begin{array}{l}\text { No difference in num- } \\
\text { ber of infections, clin- } \\
\text { ical disease stage, or } \\
\text { CD } 4+\text { count }\end{array}$ \\
\hline
\end{tabular}

* Reprinted from Mofenson LM, Shearer WT 1992 Use of IVIG in pediatric HIV infection. Semin Pediatr Infect Dis 3:1-10.

$\dagger \mathrm{LDH}$, lactate dehydrogenase. 


\section{NICHD IVIG Clinical Trial}

$$
\text { 03/01/88 - 01/16/91 }
$$

DESIGN: Phase III, Multicenter, Randomized, PlaceboControlled, Double-Blind Outpatient Study

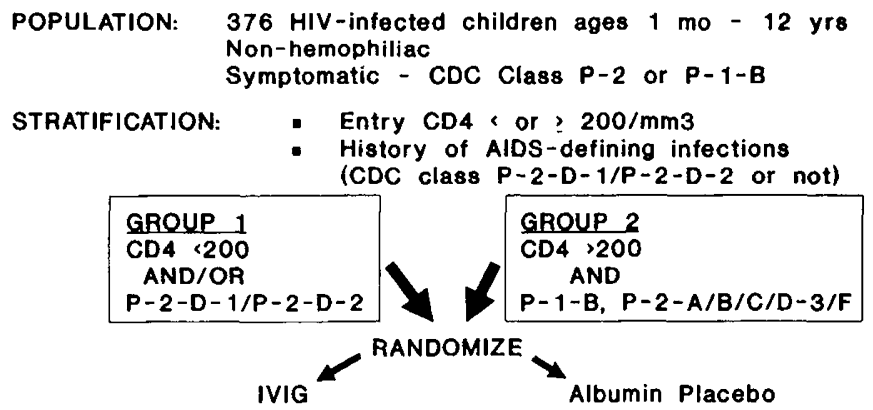

ENDPOINTS:

PRIMARY

- Reduction in serious bacterial infections or death SECONDARY

- Reduction in minor bacterial infections

- Reduction in viral infections

- Reduction in hospitalization

Fig. 2. NICHD IVIG Clinical Trial protocol design.

HIV-infected children under 13 y of age with clinical or immunologic evidence of HIV disease were eligible for entry. Fortyfive percent of children enrolled had only mild symptoms of HIV disease: $13 \%$ were clinically asymptomatic children with abnormal immune function (CDC pediatric class P1B) and $32 \%$ had clinical disease symptoms meeting the criteria for CDC pediatric class P2A only. Twenty-two percent had a history of AIDS-defining opportunistic or recurrent bacterial infections (CDC class P2D1 or P2D2) at entry. Entry CD4+ lymphocyte count was $<200 / \mathrm{mm}^{3}$ in $14 \%$.

Patients were stratified into two groups on the basis of entry CD4+ lymphocyte count and history of AIDS-defining infections. Group 1 included children with a history of AIDS-defining opportunistic or recurrent serious bacterial infections and/or an entry CD4+ lymphocyte count of $<200 / \mathrm{mm}^{3}$. Group 2 included those children with entry CD4+ lymphocyte counts of $200 / \mathrm{mm}^{3}$ or higher and immunologic abnormalities or HIV-related symptoms but without prior AIDS-defining opportunistic or bacterial infections. Children were seen monthly for examination and infusions, and information regarding all intercurrent infections, medications, and hospitalizations was collected. The initiation of antiretroviral therapy and prophylaxis for PCP (specified as trimethoprim/sulfamethoxazole on 3 consecutive d/wk) was permitted at any time after entry into the study, according to the prevailing medical standard of care as determined by the patient's physician with the consent of parents or guardians:

Definition of outcomes. Serious bacterial infections were classified as either laboratory-proven or clinically diagnosed (Fig. $3 A$ ). Laboratory-proven infections were defined as bacteriologically confirmed episodes of meningitis, bacteremia, osteomyelitis, septic arthritis, acute mastoiditis, abscess of internal organ, acute pneumonia, or acute sinusitis. Clinically diagnosed serious infections were defined as episodes of acute pneumonia or sinusitis without defined microbiologic etiology that met rigorous predetermined clinical and radiologic criteria. All reported episodes of pneumonia and sinusitis underwent central, blinded, independent review by two physicians for classification as acute laboratory-proven, as acute clinically diagnosed, or as a "not acute" episode (Fig. 3B).

Secondary analysis of "other infections" included minor bacterial infections and viral and opportunistic infections (Fig. 4). If an organism was isolated by culture, detected by antigen or histologic findings, or diagnosed by specific antibody testing, the episode was classified as laboratory proven. If the evaluating physician reported a clinical syndrome felt to be consistent with
A

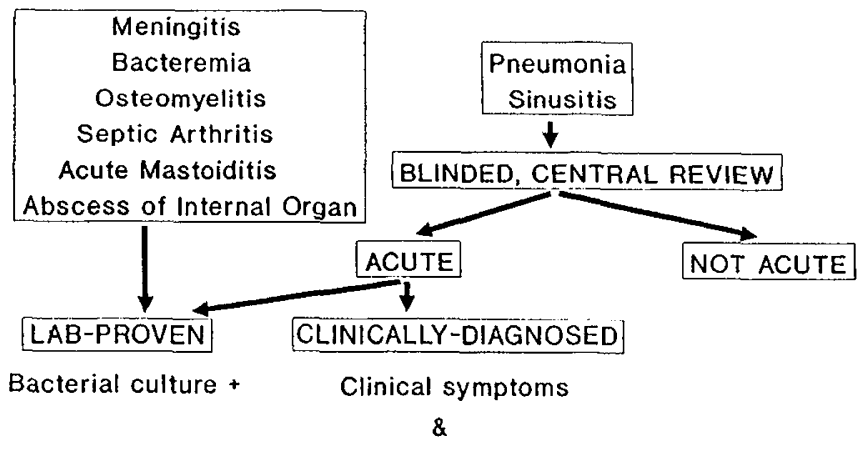

New radiologic abnormality

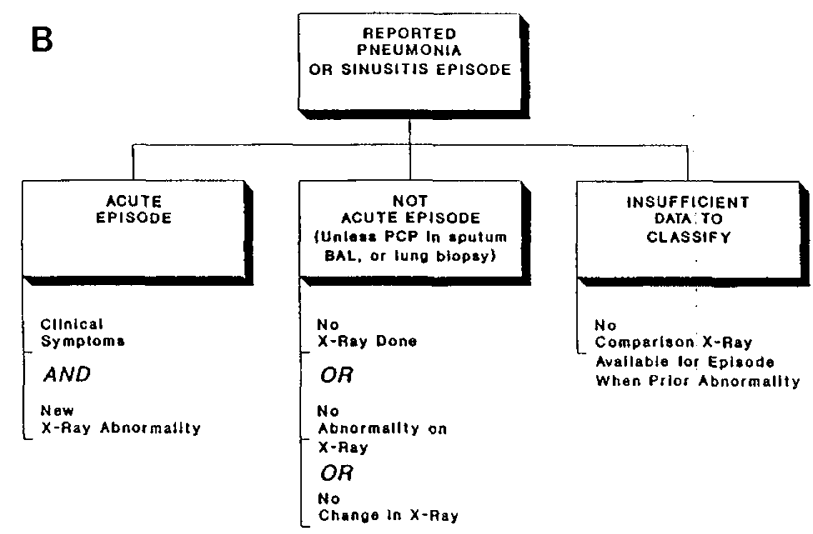

Fig. 3. Classification of serious bacterial infections in NICHD IVIG Clinical Trial. $A$ shows the definition of serious bacterial infections used in the trial; $B$ shows the criteria used for classification of clinically diagnosed pneumonia and sinusitis. $B A L$, bronchoalveolar lavage.

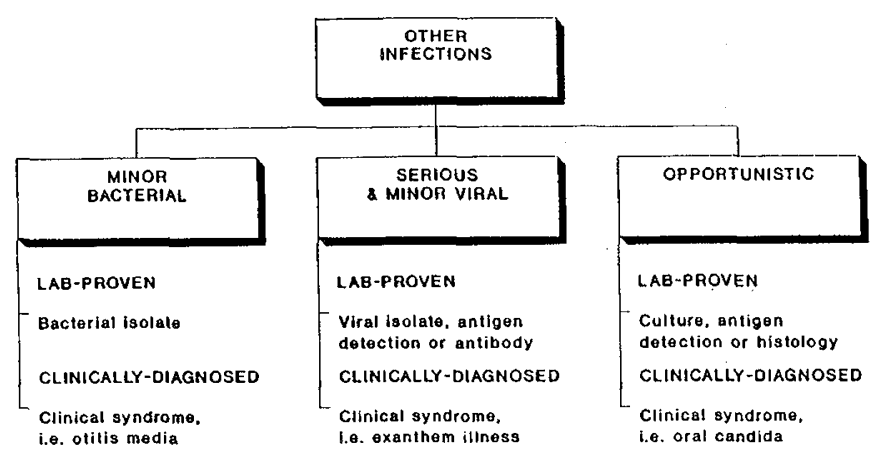

Fig. 4. Classification of other infections in NICHD IVIG Clinical Trial.

a bacterial, viral, or opportunistic etiology, the episode was classified as clinically diagnosed.

Statistical analysis. The times to first serious bacterial infection in the IVIG and placebo arms were compared by nonparametric techniques of survival analysis. The statistical significance of differences between treatment and placebo in the overall distribution of times to event were assessed with the log-rank test, using two-sided $p$ values.

For secondary analyses of the effect of IVIG on minor bacterial, viral, and opportunistic infections, differences in rates of infection between the IVIG and placebo groups per 100 patientyears were compared using hypothesis tests that assume a normal distribution. The jackknife procedure was used to estimate standard errors.

Results. Initial results, based on data collected through October 31,1990 , have been published (40). IVIG was found to significantly increase the time free of serious bacterial infection in HIV- 
infected children with an entry CD4+ count of $200 / \mathrm{mm}^{3}$ or higher $(p=0.009)$ but not in children with an entry CD4+ count of $<200 / \mathrm{mm}^{3}$; additionally, fewer overall bacterial infections, acute hospitalizations, and days spent annually in the hospital were observed in IVIG recipients with an entry CD4+ count of $200 / \mathrm{mm}^{3}$. There was no difference in mortality between IVIG and placebo; however, analysis by cause of death has not yet been completed.

The following analysis includes data collected through January 15, 1991 (the date of trial termination by the Data Safety and Monitoring Board) on 376 enrolled children with 545 patientyears of follow-up. The overall incidence of infections is summarized in Table 2. Serious laboratory-proven or clinically diagnosed bacterial infections were found in 141 patients (38\%). Clinically diagnosed serious infections occurred 2.3 times more frequently than laboratory-proven serious bacterial infections. Minor bacterial infections were 3 times as frequent as serious bacterial infections; viral infections occurred at a frequency similar to serious bacterial infections. Opportunistic infections, although infrequent, occurred at a rate similar to laboratoryproven bacterial infections.

Using events occurring through the date of trial termination, increased significance was observed for IVIG in prolonging infection-free time. Overall, IVIG patients experienced a $39 \%$ reduction in serious infections, with 91 infections in 55 IVIG patients compared with 150 infections in 86 placebo patients. In patients with an entry CD4+ count of $200 / \mathrm{mm}^{3}$ or higher, IVIG significantly prolonged the time free of serious bacterial infection $(p=0.0012)$ (Fig. 5A). Analysis confined to laboratory-proven infections similarly revealed a beneficial effect of IVIG for children with an entry CD4+ count of $200 / \mathrm{mm}^{3}$ or higher $(p=$ 0.006) (not shown).

In group 1 children with a prior history of AIDS-defining infection who had an entry CD4+ count of $200 / \mathrm{mm}^{3}$ or higher, there was a significant difference in the time free from serious infections between IVIG and placebo $(p=0.006)$ (Fig. $5 B)$, with the median time to infection over 1 y longer with IVIG (681 versus 283 d). However, for group 1 children with an entry CD4+ count of $<200 / \mathrm{mm}^{3}$ (regardless of prior history of AIDSdefining infections), no difference in the time to infection was seen with IVIG.

Children in group 2 (entry CD4+ count of $200 / \mathrm{mm}^{3}$ or higher and no prior history of AIDS-defining infection) were less likely to develop serious infections than children in group 1; however, significantly longer infection-free time with IVIG was noted ( $p$ $=0.0035)($ Fig. $5 C)$. A significant effect of IVIG was seen only after approximately 11 to $12 \mathrm{mo}$ of therapy.

The most frequent laboratory-proven infections were primary bacteremias $(74 \%)$ and pneumonia $(22 \%)$. Similar to other reports, the most common bacterial isolate was pneumococcus, accounting for $28 \%$ of all isolates. In patients with an entry CD4+ count of $200 / \mathrm{mm}^{3}$ or higher, the rate of invasive pneumococcal disease per 100 patient-years was 5.7 episodes in pla-

Table 2. Overall incidence of infections in NICHD IVIG clinical trial, March 1988 to January 1991

\begin{tabular}{lrcc}
\hline Type of infection & $\begin{array}{c}\text { No. pa- } \\
\text { tients }\end{array}$ & $\begin{array}{c}\text { No. epi- } \\
\text { sodes }\end{array}$ & $\begin{array}{c}\text { Infection rate } \\
\text { per patient-year }\end{array}$ \\
\hline $\begin{array}{l}\text { Serious bacterial } \\
\text { Lab-proven or clini- }\end{array}$ & 141 & 241 & 0.44 \\
$\quad$ cally diagnosed & & & \\
$\quad$ Clinically diagnosed & 116 & 167 & 0.31 \\
$\quad$ Lab-proven & 54 & 74 & 0.14 \\
Other infections & & & \\
$\quad$ Minor bacterial & 243 & 771 & 1.42 \\
Viral & 156 & 266 & 0.49 \\
Opportunistic & 53 & 90 & 0.17 \\
\hline
\end{tabular}

* Modified from Mofenson LM, Shearer WT 1992 Use of IVIG in pediatric HIV infection. Semin Pediatr Infect Dis 3:1-10.
All Children with Entry CD4 $\gg 200 / \mathrm{mm}^{3}$, Groups 182 Combined

A

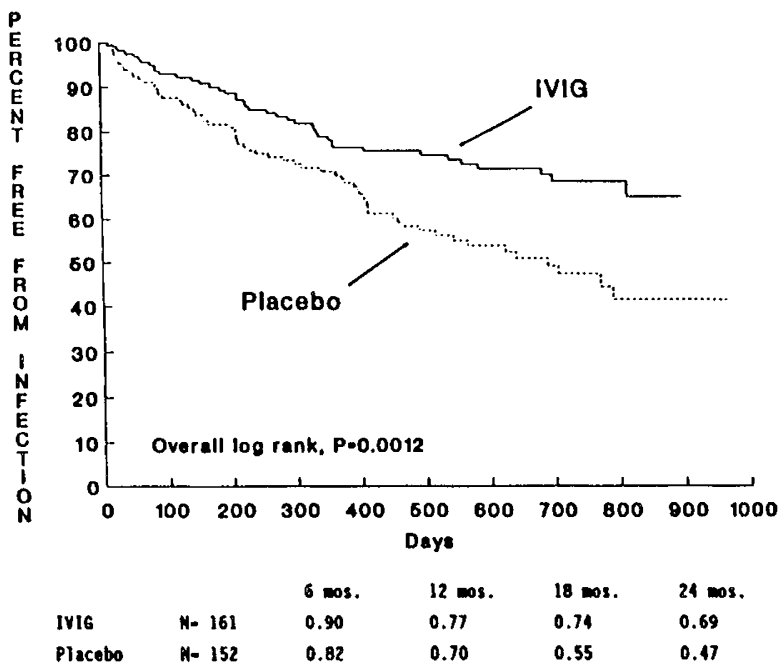

B
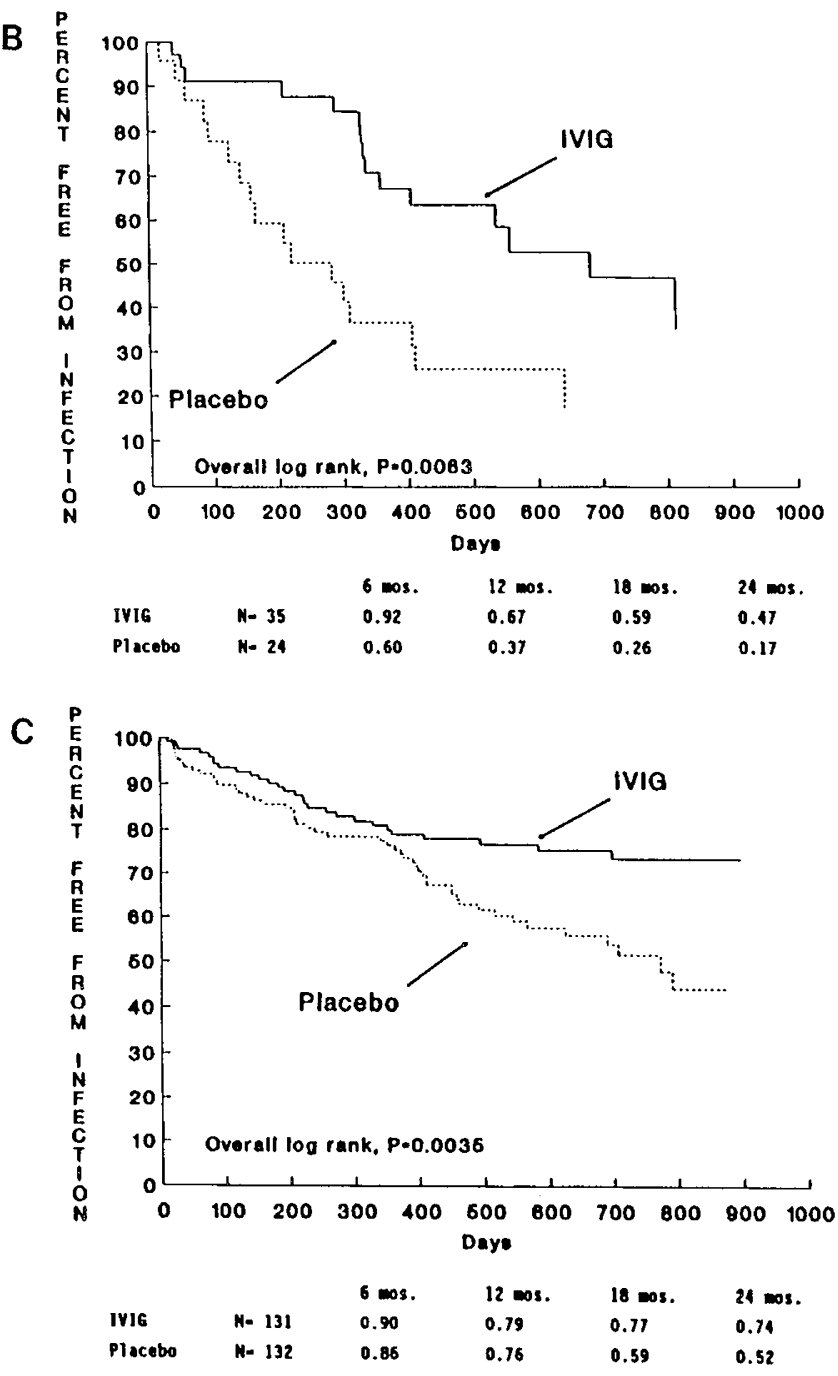

Fig. 5. Probability of remaining free of laboratory-proven and clinically diagnosed serious bacterial infections in study children assigned to IVIG (solid line) or placebo (dashed line) in NICHD IVIG Clinical Trial, March 1988-January 1991. Modified from reference 5. A shows all study children with entry $\mathrm{CD} 4+$ cell counts $\geq 200 / \mathrm{mm}^{3}$ ( $p=0.0012$ by the overall log-rank test for the comparison of the study arms); $B$ shows group 1 children with entry CD4+ cell counts $\geq 200 / \mathrm{mm}^{3}(p=0.006)$; 
Table 3. NICHD IVIG clinical trial March 1988 to January 1991: effect of IVIG on selected infections in patients with entry $\mathrm{CD} 4+\geq 200 / \mathrm{mm}^{3 *}$

\begin{tabular}{lcc}
\hline & $\begin{array}{c}\text { IVIG } \dagger \\
(n=161)\end{array}$ & $\begin{array}{c}\text { Placebo } \\
(n=152)\end{array}$ \\
\hline Serious bacterial infections & & \\
Lab-proven or clinically diagnosed & $26.4 \$$ & 48.2 \\
Lab-proven: & & \\
$\quad$ Streptococcus pneumoniae & 2.0 & 5.7 \\
$\quad$ Other bacteria & 4.0 & 8.9 \\
Clinically diagnosed: & & \\
Acute pneumonia & 10.0 & 23.9 \\
$\quad$ Acute sinusitis & 10.4 & 9.7 \\
Other infections & $115.1 \S$ & 159.7 \\
Minor bacterial & 63.5 & 99.5 \\
Otitis & 14.0 & 23.0 \\
Skin/soft tissue & 10.8 & 15.9 \\
Upper respiratory tract & $36.0 \|$ & 54.0 \\
Viral & 7.6 & 13.7 \\
Herpes simplex virus & 10.0 & 13.3 \\
Opportunistic & 6.4 & 10.6 \\
Candida species & 1.2 & 0.4 \\
$\quad$ Pneumocystis carinii &
\end{tabular}

* Modified from Mofenson LM, Shearer WT, Moye J, Nugent R, Willoughby A, for the NICHD Study Group 1992. Letter to the editor. N Engl J Med 326:1636-1637.

$\uparrow$ Rate of infection per 100 patient-years.

$\ddagger p=0.002$, comparing rate per 100 patient-years, IVIG $v s$ placebo.

$\S p=0.02$, comparing rate per 100 patient-years, IVIG $v s$ placebo.

$\| p=0.01$, comparing rate per 100 patient-years, IVIG vs placebo.

cebo patients compared with 2.0 in IVIG patients (Table 3 ). IVIG was associated with a decrease in pneumococcal disease regardless of PCP prophylaxis status: of the 18 episodes of pneumococcal disease occurring in patients with entry CD4+ counts of $200 / \mathrm{mm}^{3}$ or higher, five occurred in placebo and two in IVIG patients who were receiving PCP prophylaxis at least 1 mo before the event occurred, and eight occurred in placebo and three in IVIG patients who were not receiving prophylaxis before the event. Although the overall occurrence of serious infections with other bacteria was also decreased with IVIG, infections with other bacterial species were too few to make meaningful individual comparisons.

Acute pneumonia was the most common clinically diagnosed serious infection (66\%), followed by acute sinusitis. There was a $53 \%$ decrease in the rate of acute clinically diagnosed pneumonia per 100 patient-years in IVIG recipients with entry CD4+ counts of $200 / \mathrm{mm}^{3}$ or higher (Table 3 ).

Six hundred forty-nine minor bacterial infections were observed in 205 children with entry CD4+ counts of $200 / \mathrm{mm}^{3}$ or higher. Nearly $60 \%$ involved the ear, $13 \%$ skin and soft tissue, and $10 \%$ upper respiratory tract. Significantly fewer minor bacterial infections per 100 patient-years occurred with IVIG in patients with entry $\mathrm{CD} 4+$ counts of $200 / \mathrm{mm}^{3}$ or higher $(p=$ 0.02 ) (Table 3). IVIG was associated with decreases in rates per 100 patient-years of $36 \%$ for otitis, $39 \%$ for skin/soft tissue infections, and $32 \%$ for upper respiratory tract infections.

Similarly, significantly fewer viral infections per 100 patientyears were observed with IVIG in patients with entry CD4+ counts of $200 / \mathrm{mm}^{3}$ or higher $(p=0.01)$ (Table 3$)$. Two hundred twelve viral infections were diagnosed in 129 patients in this group. Of infections with a specified etiology, over $50 \%$ were due to herpes simplex virus. There were $45 \%$ fewer herpes simplex virus infections in IVIG recipients. For viral infections with a specified etiology, those agents for which humoral immunity is

and $C$ shows group 2 children ( $p=0.0035$ ). The estimated proportion of children in each study arm remaining infection-free at $6,12,18$, and 24 mo is indicated beneath each graph. traditionally associated with prevention of infection were decreased in IVIG recipients. All five of the reported cases of measles, two of two enteroviral infections, and the single case of hepatitis A occurred in placebo patients.

There were 55 opportunistic infections in 34 patients with entry CD4+ counts of $200 / \mathrm{mm}^{3}$ or higher. The most frequent infection was with Candida, accounting for $73 \%$ of infections, followed by PCP (7\%); all other etiologies accounted for $5 \%$ or less. There was a similar frequency of opportunistic infections in IVIG and placebo children (Table 3).

Detailed analysis has been done to evaluate the interaction of IVIG and concomitant therapy with trimethoprim/sulfamethoxazole administered $3 \mathrm{~d} / \mathrm{wk}$ for PCP prophylaxis or with ZDV (41). As of January 1991, when the study ended, $50 \%$ of study patients with an entry CD4+ count of $200 / \mathrm{mm}^{3}$ or higher had received PCP prophylaxis (50\% of placebo and $49 \%$ of IVIG patients) and $45 \%$ had received ZDV (47\% of placebo and $44 \%$ of IVIG patients). Time to initiation of either therapy was similar in both groups.

For minor bacterial infections and viral infections, risk ratios (IVIG versus placebo) were used to compare the relative risk of infection before and after beginning ZDV therapy or PCP prophylaxis. No significant differences were found for either minor bacterial infections or viral infections for ZDV $(p \geq 0.15)$ or PCP prophylaxis $(p \geq 0.19)$.

Both logistic and linear regression models were used to evaluate the interactive effects of IVIG, PCP prophylaxis, and ZDV therapy on rates of infection. Regardless of either ZDV therapy or PCP prophylaxis, IVIG reduced the chance of minor bacterial infection $(p=0.05)$, the number of minor bacterial infections among those having more than one infection $(p=0.03)$, and the number of viral infections among those having more than one infection $(p=0.06)$. There was no significant interaction either between IVIG and ZDV $(p=0.11)$ or between IVIG and PCP prophylaxis $(p=0.43)$ in the rates of minor bacterial infections, and there was no significant interaction between IVIG and either ZDV therapy or PCP prophylaxis in rates of viral infections $(p$ $\geq 0.17$ ).

Survival curves, using right-censored (only events occurring before initiation of PCP prophylaxis or ZDV) and left-censored (events occurring after initiation of PCP prophylaxis or ZDV) data were used to compare time free of serious bacterial infection between IVIG and placebo; in all cases IVIG was associated with improvement in infection-free time. As discussed previously, placebo patients experienced episodes of pneumococcal disease on or off PCP prophylaxis before an event, and patients receiving IVIG experienced fewer episodes regardless of PCP prophylaxis status.

A proportional hazards analysis was performed to look for possible interactions between IVIG and either PCP prophylaxis or ZDV therapy in terms of time to first serious bacterial infection. Specifically, PCP prophylaxis and ZDV therapy were used as time-dependent covariates (22). The resulting analysis indicated that the previously discussed effect of IVIG was of the same magnitude before and after the use of either PCP prophylaxis or ZDV. ZDV use was associated with a nonsignificant prolongation of time to serious bacterial infection, whereas PCP prophylaxis was associated with a decrease in time to serious bacterial infection, presumably a reflection that children who developed infections were more likely to be placed on prophylaxis.

\section{DISCUSSION}

Treatment with IVIG was safe and well tolerated, with benefit seen across several infectious outcome parameters. In IVIGtreated children who entered the trial with a CD4+ count of $200 / \mathrm{mm}^{3}$ or higher, treatment significantly increased the time free from serious bacterial infections and significantly reduced 
the number of minor bacterial infections and viral infections (42).

As in other studies, $S$. pneumoniae was the most common identified etiology of serious bacterial infection; IVIG therapy was associated with a $62 \%$ decrease in pneumococcal disease in patients with entry CD4+ counts of $200 / \mathrm{mm}^{3}$ or higher. PCP prophylaxis as administered in this study and currently recommended by the Public Health Service (trimethoprim/sulfamethoxazole given $3 \mathrm{~d} / \mathrm{wk}$ ) (22) did not appear to significantly affect the incidence of pneumococcal disease or alter the benefit of IVIG. However, the influence of a daily regimen of antibiotic prophylaxis remains to be determined.

Repeated episodes of acute pneumonia cause significant morbidity in HIV-infected children. In a recent report, $70 \%$ of a cohort of HIV-infected children from New York City required hospital admission for an acute respiratory illness with no identified pathogen, and $30 \%$ developed laboratory-proven bacterial pneumonia (15). In our study, acute pneumonia, the majority clinically diagnosed, was the most frequently observed serious infection. The rate of acute laboratory-proven or clinically diagnosed pneumonia episodes in placebo-arm patients with entry CD4+ counts of $200 / \mathrm{mm}^{3}$ or higher (26 episodes per 100 patientyears) was more than 6 times greater than that reported for healthy preschool children (43). IVIG therapy was associated with a $53 \%$ decrease in acute laboratory-proven bacterial or clinically diagnosed pneumonia episodes per 100 patient-years in patients with entry CD4+ counts of $200 / \mathrm{mm}^{3}$ or higher.

Viral infections were a significant cause of morbidity in this cohort. IVIG therapy was associated with a significant decrease in viral infections, particularly herpes simplex virus, in patients with entry CD4+ counts of $200 / \mathrm{mm}^{3}$ or higher. Although cellular immunity is thought to play a major role in prevention of recurrent herpes simplex infection, recent data have suggested that antibody-dependent cellular cytotoxicity may also play a significant role $(44,45)$. It would be anticipated that a protective effect of antibody would therefore depend upon a relatively intact cellular immune system, as might be seen in those children with CD $4+$ counts of $>200 / \mathrm{mm}^{3}$.

Limitations of IVIG therapy were noted. In group 2 patients, there was some delay before a treatment effect was seen for serious infections. This may be related to the low incidence of events in these patients, who had less advanced HIV disease, and the likelihood that infectious complications may not increase in frequency until immunologic attrition occurs, i.e. loss of T-helper recall antigen response (29). In addition, because the half-life of $\mathrm{IgG}$ is reduced in hypergammaglobulinemic states (46), attainment of a month-long protective effect of IVIG may be delayed in HIV-infected patients. In patients with primary immunodeficiency receiving monthly IVIG, serum IgG levels show a stepwise increase in peak and trough levels after the first four to six infusions before reaching a protective plateau (47). The optimal dose and frequency of IVIG administration in pediatric HIV infection remains to be determined. Further data analysis to evaluate the timing of infectious events in relation to time of IVIG infusion is planned.

In children who entered the trial with CD4+ counts of $<200 /$ $\mathrm{mm}^{3}$, no significant improvement was noted. The limited number of children with entry CD4+ counts of $<200 / \mathrm{mm}^{3}$ (50 total patients) decreases the power of this study to detect such a difference and conclusions regarding the effectiveness of IVIG in this population cannot be drawn from this study. However, it is possible that adjunctive immunotherapy with IVIG is most effective in those children with mild-to-moderate immunologic dysfunction with some preservation of $T$-helper cell function. In such children, therapy may compensate for defects in T-helper recall antigen response and provide protection against a variety of bacterial and viral pathogens through provision of specific antibody as well as enhancement of antibody-dependent cytotoxicity. As immunologic function continues to deteriorate, the combination of $\mathrm{CD} 4+$ cell depletion coupled with severe dys- function of the residual $\mathrm{T}$-helper cell population may be too severe to overcome through provision of antibody alone. Therapies that may be successful at one level of immune dysfunction may not be sufficient with increasing levels of dysfunction.

\section{ACTG PROTOCOL 051}

Although ZDV therapy during the NICHD IVIG Clinical Trial did not alter the results, the NICHD trial was not designed to evaluate the efficacy of IVIG in children already receiving ZDV. The National Institutes of Health is also sponsoring a doubleblind, placebo-controlled trial to evaluate IVIG in children with severely symptomatic HIV infection (AIDS or AIDS-related complex) receiving ZDV (ACTG protocol 051). This trial, which has completed enrollment with 262 patients, closed to accrual on August 16, 1990 and is currently ongoing. The sample size requirements of ACTG 051 assume an infection rate of $25 \%$ after $24 \mathrm{mo}$ and an IVIG treatment effect of $60 \%$; lower infection rates or treatment effects less than $60 \%$ may limit the ability of the trial to detect a significant treatment difference. The observed overall treatment effect of IVIG in the NICHD IVIG Clinical Trial at the time of study termination was 39\%; however, the patient population in the NICHD trial was less severely symptomatic than that in ACTG 051.

In some studies, $\mathrm{ZDV}$ has been demonstrated to improve $\mathrm{T}$ helper and other immune cell function (48-50). Although the immunologic correlates of infection risk in HIV-infected children have not been well delineated, it is possible that $\mathrm{ZDV}$, by delaying the time to immunologic deterioration, could prolong an infection "risk-free" period, during which adjunctive immunotherapy may not be necessary. Further evaluation of data from the NICHD IVIG Clinical Trial, as well as ACTG 051, may better delineate the subgroup of HIV-infected children most likely to benefit from IVIG therapy.

It is important to note, however, that the effect of ZDV in enhancing immunologic and clinical status appears to be transient $(51,52)$. Because the natural history of HIV infection, even in the treatment era, appears to be one of progressive immunodeficiency, serial combinations of antiretroviral therapy, antibiotic prophylaxis to prevent PCP, immunomodulator therapy such as IVIG, and other adjunctive therapies may be necessary to prevent the eventual development of a downward cycle of increasingly opportunistic infections in the HIV-infected child.

\section{REFERENCES}

1. Lane HC, Fauci AS 1985 Immunologic abnormalities in the acquired immunodeficiency syndrome. Annu Rev Immunol 3:477-500

2. Ammann AJ, Schiffman G, Abrams D, Volberding P, Ziegler J, Conant M 1984 B-cell immunodeficiency in acquired immunodeficiency syndrome. JAMA 251:1447-1449

3. Pahwa S, Fikrig S, Menez R, Pahwa R 1986 Pediatric acquired immunodeficiency syndrome: demonstration of $\mathrm{B}$ lymphocyte defects in vitro. Diagn Immunol 4:24-30

4. Bernstein LJ, Ochs HD, Wedgwood RJ, Rubinstein A 1985 Defective humoral immunity in pediatric acquired immunodeficiency syndrome. J Pediatr 107:352- 357

5. Mofenson LM, Shearer WT 1992 Use of IVIG in pediatric HIV infection. Semin Pediatr Infect Dis 3:1-10

6. Yap PL, Todd AAM, Williams PE, Hague RA, Mok J, Burns SM, Brettle RP 1991 Use of intravenous immunoglobulin in acquired immune deficiency syndrome. Cancer 68(suppl): $1440-1450$

7. Centers for Disease Control 1987 Revision of the CDC surveillance case definition for acquired immunodeficiency syndrome. MMWR 36(suppl): 1S$15 \mathrm{~S}$

8. Oxtoby MJ 1991 Perinatally acquired HIV infection. In: Pizzo PA, Wilfert CM (eds) Pediatric AIDS: The Challenge of HIV Infection in Infants, Children and Adolescents. Williams \& Wilkins, Baltimore, pp 3-21

9. Bernstein LJ, Krieger BZ, Novick B, Sicklick MJ, Rubinstein A 1985 Bacterial infection in the acquired immunodeficiency syndrome of children. Pediatr Infect Dis J 4:472-475

10. Krasinski K, Borkowsky W, Bonk S, Lawrence R, Chandwani S 1988 Bacterial infections in human immunodeficiency virus-infected children. Pediatr Infect Dis J 7:323-328

11. Roilides E, Marshall D, Venzon D, Butler K, Husson R, Pizzo RA 1991 Bacterial infections in human immunodeficiency virus type 1-infected chil- 
dren: the impact of central venous catheters and antiretroviral agents. Pediatr Infect Dis J 10:813-819

12. Hsu H, Moye J, Ng P, Shea B, Mofenson L, Kunches L, Tobin S, DeMaria A, Grady G, McIntosh K, Meissner C, Pasternack M, Pelton S, Stechenberg B, Sullivan J, and the Massachusetts Working Group on Surveillance 1991 Pneumococcal bacteremia in children with HIV infection. Program and Abstracts of the VII International Conference on AIDS, Florence, Italy (abstr W.B. 2062)

13. Zarkowsky HS, Gallagher D, Gill FM, Wang WC, Falletta JM, Lande WM, Levy PS, Verter JI, Wethers D, and the Cooperative Study of Sickle Cell Disease 1986 Bacteremia in sickle hemoglobinopathies. J Pediatr 109:579_ 585

14. Redd SC, Rutherford GW, Sande MA, Lifson AR, Hadley WK, Facklam RR, Spika JS 1990 The role of human immunodeficiency virus infection in pneumococcal bacteremia in San Francisco residents. J Infect Dis 162:10121017

15. Marolda J, Pace B, Bonforte RJ, Kotin NM, Rabinowitz J, Kattan M 1991 Pulmonary manifestations of HIV infection in children. Pediatr Pulmonol 10:231-235

16. Principi N, Marchisio P, Tornaghi R, Massironi E, Onorato J, Picco P, Libretti C 1991 Occurrence of infections in children infected with human immunodeficiency virus. Pediatr Infect Dis J 10:190-193

17. Principi N, Marchisio P, Tornaghi R, Onorato J, Massironi E, Picco P 1991 Acute otitis media in human immunodeficiency virus-infected children. Pediatrics 88:566-57

18. Stiehm ER, Wara DW 1991 Immunology of HIV. In: Pizzo PA, Wilfert CM (eds) Pediatric AIDS: The Challenge of HIV Infection in Infants, Children and Adolescents. Williams \& Wilkins, Baltimore, pp 95-112

19. Leibovitz E, Riguad M, Pollack H, Lawrence R, Chandwani S, Krasinski K, Borkowsky W 1990 Pneumocytis carinii pneumonia in infants infected with the human immunodeficiency virus with more than $450 \mathrm{CD} 4 \mathrm{~T}$ lymphocytes per cubic millimeter. N Engl J Med 323:531-533

20. Kovacs A, Frederick T, Church J, Eller A, Oxtoby M, Mascola L 1991 CD4 T-lymphocyte counts and Pneumocystis carinii pneumonia in pediatric HIV infection. JAMA 265:1698-1703

21. Centers for Disease Control 1991 Guidelines for prophylaxis against Pneumocystis carnii pneumonia for children infected with human immunodeficiency virus. MMWR 40(suppl)RR-2:1-13

22. Denny TN, Niven P, Skuza C, Chadwick EG, Kriger L, Amer M, Connor EM, Oleske JM, Yogev R 1990 Lymphocyte subsets identified by monoclonal antibodies in healthy children. Pediatr Res 27:155A(abstr 916)

23. European Collaborative Study 1991 Children born to women with HIV-1 infection: natural history and risk of transmission. Lancet 337:253-260

24. Klee EB, Jackson DJ, Green SDR, Mokili JLK, Cutting WAM 1991 Immunoglobulins and B-2 microglobulin in HIV-1 infected children in rural Zaire. AIDS 5:1032-1034

25. Pahwa S, Fikrig S, Menez R, Pahwa R 1986 Pediatric acquired immunodeficiency syndrome demonstration of B-lymphocyte defects in-vitro. Diagn Immunol 4:24-30

26. Borkowsky W, Steele CJ, Grubman S 1987 Antibody responses to bacterial toxoids in children infected with human immunodeficiency virus. J Pediatr 110:563-566

27. Shearer GM, Clerici M 1991 Early T-helper cell defects in HIV infection. AIDS 5:245-253

28. Lucey DR, Melcher GP, Hendrix CW, Zajac RA, Goetz DW, Butzin CA Clerici M, Warner RD, Abbadessa S, Hall K, Jaso R, Woolford B, Miller S, Stocks NI, Salinas CM, Wolfe WH, Shearer GM, Boswell RN 1991 Human immunodeficiency virus infection in the US Air Force: seroconversions, clinical staging and assessment of a $\mathrm{T}$-helper functional assay to predict change in CD4+ T cell counts. J Infect Dis 164:631-637

29. Roilides E, Clerici M, DePalma L, Rubin M, Pizzo PA 1991 Helper T-cell responses in children infected with human immunodeficiency virus type 1 . J Pediatr 118:724-730

30. Mofenson LM, Willoughby A 1991 Passive immunization. In: Pizzo PA, Wilfert CM (eds) Pediatric AIDS: The Challenge of HIV Infection in Infants, Children and Adolescents. Williams \& Wilkins, Baltimore, pp 633-650

31. Silverman BA, Rubinstein A 1985 Serum lactate dehydrogenase levels in adults and children with AIDS: possible indicator of B cell lymphoproliferative and disease activity; effect of IVIG on enzyme levels. Am J Med 78:728-736

32. Gupta A, Novick BE, Rubinstein A 1986 Restoration of suppressor T-cell functions in children with AIDS following intravenous gamma globulin treatment. Am J Dis Child 140:143-146

33. Wood CC, McNamara JG, Schwarz DF, Merrill WW, Shapiro ED 1987 Prevention of pneumococcal bacteremia in a child with ARC. Pediatr Infect Dis J 6:564-566

34. Schaad UB, Gianella-Borradori A, Perret B, Imbach P, Morell A 1988 Intravenous immune globulin in symptomatic paediatric human immunodeficiency virus infection. Eur J Pediatr 147:300-303

35. Williams PE, Hague RA, Yap PL, Mok J, Brettle RP, Coutts NA, Eden OB, Watson JG 1988 Treatment of human immunodeficiency virus antibody children with intravenous immunoglobulin. J Hosp Infect 12(suppl D):6773

36. Hague RA, Yap PL, Mok JY, Eden OB, Coutts NA, Watson JG, Hargreaves FD, Whitelaw JM 1989 Intravenous immunoglobulin in HIV infection: evidence for efficacy of treatment. Arch Dis Child 64:1146-1150
37. Calvelli TA, Rubenstein A 1986 Intravenous gamma globulin in infantacquired immunodeficiency syndrome. Pediatr Infect Dis J 5:S207-S210

38. Siegal FP, Oleske JM 1986 Management of the acquired immunodeficiency syndrome: is there a role for immune globulin? In: Morell A, Hydeggar AE (eds) Clinical Use of Intravenous Immunoglobulins. Academic Press, London, pp 373-384

39. Wagner N, Bialek R, Radinger H, Becker M, Brackmann H 1991 Intravenous immunoglobulins in HIV-infected hemophiliac children and adolescents: a randomized controlled trial over 24 mo. Program and Abstracts of the VII International Conference on AIDS, Florence, Italy (abstr W.B. 2067)

40. NICHD IVIG Clinical Trial Study Group 1991 Efficacy of intravenous immunoglobulin for the prophylaxis of serious bacterial infections in symptomatic HIV-infected children. N Engl J Med 325:73-80

41. Mofenson LM, Bethel J, Moye J, for the NICHD IVIG Clinical Trial Study Group 1992 Effect of intravenous immunoglobulin, PCP prophylaxis, and AZT on prevention of infections in HIV-infected children. Pediatr Res 31:170A(abstr 1008)

42. Mofenson LM, Moye J, Bethel J, Hirschhorn R, Jordan C, Nugent R, for the NICHD IVIG Clinical Trial Study Group 1992 Prophylactic intravenous immunoglobulin in HIV-infected children with CD4+ counts of $0.20 \times 10^{\circ} /$ $\mathrm{L}$ or more; effect on viral, opportunistic, and bacterial infections. JAMA 268:483-488

43. Murphy TF, Henderson FW, Clyde WA, Collier AM, Denny FW 1981 Pneumonia: an 11-year study in a pediatric practice. Am J Epidemiol 113:12-21

44. Kohl S 1991 Role of antibody-dependent cellular cytotoxicity in defense against herpes simplex infections. Rev Infect Dis 13:108-114

45. Mester JC, Glorioso JC, Rouse BT 1991 Protection against zosteriform spread of herpes simplex virus by monoclonal antibodies. J Infect Dis 163:263-269

46. Morell A, Terry MD, Waldmann TA 1970 Metabolic properties of IgG subclasses in man. J Clin Invest 49:673-680

47. Ochs HD, Fischer SH, Wedgwood RJ, Wara DW, Cowan MJ, Amman AJ, Saxon A, Budinger MD, Allred RU, Rousell RH 1984 Comparison of highdose and low-dose intravenous immunoglobulin in patients with primary immunodeficiency diseases. Am J Med 76(suppl 3A):78-82

48. Roilides E, Venzon D, Pizzo PA, Rubin M 1990 Effects of antiretroviral dideoxynucleosides on polymorphonuclear leukocyte function. Antimicrob Agents Chemother 34:1672-1677

49. Roilides E, Clerici M, Butler K, Gress J, Pizzo PA, Shearer GM 1990 Improvement of $\mathrm{T}$ helper cell function on dideoxyinosine therapy: correlation with the clinical improvement of HIV-infected children. Programs and Abstracts of the 30th Interscience Conference on Antimicrobial Agents and Chemotherapy Atlanta, GA (abstr 428)

50. Rinaldo C, Huang XL, Piazza P, Armstrong J, Rappocciolo G, Pazin G, McMahon D, Gupta P, Fan Z, Zhang Z, Ho M 1991 Augmentation of cellular immune function during the early phase of zidovudine treatment of AIDS patients. J Infect Dis 164:638-645

51. Yarchoan R 1990 Taking drugs from the test tube to patients (pp 607-612). In: Broder S, moderator. Antiretroviral therapy in AIDS (NIH Conference). Ann Intern Med 113:604-618

52. Fischl MA, Richmann DD, Grieco MH, Gottlieb MS, Volberding PA, Laskin OL, Leedom JM, Groopman JE, Mildvan D, Schooley RT 1987 The efficacy of azidothymidine (AZT) in the treatment of patients with AIDS and AIDSrelated complex: a double-blind, placebo-controlled trial. $\mathbf{N}$ Engl $\mathbf{J}$ Med $317: 185-191$

\section{FLOOR DISCUSSION}

Dr. Schreiber: I want to suggest an alternative potential explanation for your consideration, which was not in your article in the New England Journal of Medicine. Perhaps an Fc receptor defect is present within macrophages and in patients with AIDS and is one mechanism that predisposes these patients to bacterial infection. One would expect patients who have a high CD4+ cell population to respond better to IVIG because those patients would be more likely to have bacterial infections than those who have low CD4 levels and might have a T-cell-mediated host response. Patients who have adequate CD4+ cells would be using antibody Fc-dependent mechanisms in clearing bacterial infection and one would suspect that the presentation of antibody intravenously might overcome their Fc receptor defect. I would have predicted that you would see a decrease in the incidence of bacterial infections in the spectrum of patients that you have seen, and I would have predicted that the decrease would occur in the patients who have adequate CD4+ cells because they would be more likely to have bacterial infection that could be correctable by the presentation of antibody through IVIG. One approach would be to demonstrate that those patients who have the increased incidence of infection that is corrected by IVIG are the ones with an $F c$ receptor defect. We used that kind of rationale in chronic renal failure and reported our findings, in 
an article in the New England Journal of Medicine, showing that the severity of bacterial infection correlated with the severity of the macrophage $\mathrm{Fc}$ receptor defect.

Dr. Mofenson: I wish that we had cells saved; however, we do have serum saved from the children. When the study was designed in 1987, the issues around differential loss of recall antigen were not as well known. It would be very interesting to look at recall and alloantigen function in these children, but we just do not have the cells to do that.

Dr. Steigbigel: Although you observed a decrease in a variety of measures of bacterial infection, the time to death did not change. Was there an analysis of what the causes of death were and was there a substitution of different causes in one group versus the other?

Dr. Mofenson: We have not done an analysis by cause of death. While the study was ongoing, we presented a paper at ICAAC (Interscience Conference on Antimicrobial Agents and Chemotherapy) about the diagnosis of pneumonia in study children. At that time, a brief blinded review of death for pneumonias was done. We found that most of the deaths were associated with opportunistic infection. There were maybe one or two deaths that I remember reviewing in which sepsis or bacterial infection was the primary cause of death. There were a number of deaths that were due to cardiomyopathy, nephropathy, some that were due to Candida, meningitis, or CMV (cytomegalovirus) disease, but very few were related to bacterial infections per se. We need to go back and do a blinded, independent review of cause of death to do that curve over again.

Dr. Steigbigel: So in that the time to death was not changed, the benefit in terms of the total patient care would have to rest a lot on quality-of-life issues.

Dr. Mofenson: Yes.

Dr. Steigbigel: Do you have any data on the total hospital time, including the time that the patient is hooked up to IVIG?

Dr. Mofenson: The IVIG was administered as outpatient therapy. We do have data on hospital days, and it was reported in our original paper. There were significantly fewer hospitalizations in the IVIG-treated patients. We limited ourselves to acute care hospitalization and found about 38 fewer hospitalizations per 100 patient-years in the IVIG group. I would like to go back and look at cause of hospitalization because I think it would be even more significant if we looked specifically at infection-related hospitalizations.

Dr. Rubinstein: From 1979 to 1981 , we treated children with pediatric AIDS without knowing that they had pediatric AIDS, knowing only that they had a B-cell deficiency. We gave IVIG in the same manner as our treatment of agammaglobulinemic patients and we found that the once-monthly regimen did not give us the same benefit as more frequent regimens. I recall one child who had three recurrent episodes of pneumococcal sepsis, each one at the end of the period after receiving IVIG. We looked at levels of pneumococcal antibodies in this child $4 \mathrm{wk}$ after the previous gamma globulin infusion, and they were nonexistent. That was why we moved to more frequent infusions, and we still continue that regimen in those of our children who are not in your study. Those in your study receive IVIG once monthly, but those that are on our study are given IVIG every other week.

The second finding that was obvious in the studies was that we did not see the immunomodulatory effect of IVIG in the same manner as we do in CVID (common variable immunodeficiency). One of the parameters we looked at was immune complexes. When we gave the IVIG once monthly, as reported in our paper in 1985, the immune complexes went down, only to bounce back up after $4 \mathrm{wk}$ to the same level as before. When we gave IVIG more frequently, we could reduce circulating immune complexes only with a biweekly infusion. My question to you is, now that you have analyzed the infections and shown that the increased infection rate appears at the longest interval after the infusion, would you recommend a more frequent infusion of IVIG to these children?
Dr. Mofenson: Well, as I have said, this is very preliminary data. I saw the data on rate of infection from time of infusion only a few days ago. It is just an initial run and we are looking at a variety of different things. I think that this study did not answer all the questions; I think it has raised even more questions. The optimal dose, the optimal timing, the optimal population remain to be decided. I am hoping that when the other ACTG trial $(051)$ is over we will sit down together, compare the data and the patient populations, and hold a concensus conference to be able to help the clinician know what to do. When people ask me now, my answers are as a clinician and not as an NIH staff member! I will be happy to do that away from the microphone.

Dr. Wara: All $I$ hope is that when this consensus conference is held you all can figure out a way to infuse IVIG no more frequently than once a month, because we are not going to be able to handle it otherwise.

Dr. Stiehm: I have never seen a case of varicella on IVIG. I am wondering if there were extenuating circumstances; for example, could these children have had severe diarrhea and lost all their gamma globulin if they got the varicella at the end of the period, or did they have extremely high levels of gamma globulin, which greatly increases IVIG catabolism? It would be interesting to analyze those specific cases.

Dr. Mofenson: I have divided them into primary varicella and zoster. Some of those primary varicellas may be the phenomenon called recurrent varicella. When you think about the use of IVIG versus hyperimmune globulin, you don't give IVIG when you are trying to prevent varicella, you give hyperimmune VZIG (varicella-zoster immune globulin); but when you want to prevent measles, you give immune serum globulin. I think it says something about the concentration of antibody that may be needed to prevent infections in the two groups. After thinking about the difference between herpes simplex and varicella and about the fact that we give VZIG, I was not completely surprised that there were a similar number of cases. It was somewhat less in the IVIG-treated group but not significantly less.

Dr. Stiehm: VZIG is given intramuscularly and IVIG, of course, gives about a comparable level of antibody. There have been studies on that.

Dr. Fischer: You showed a very interesting association between the IVIG and the change in the decline of the CD4 counts. You may already know the answer to an important question. That is, is this a specific effect of IVIG on organisms, thus decreasing episodes of infection in these children? Did those who had decreased episodes have less decline in CD4 counts, or did all the children, even those who did not have a decreased number of episodes or very few infections, also have a decline in CD4 counts? That could be very important in deciding which IVIG should be used.

Dr. Mofenson: The CD4 count data has also just been analyzed. The problem is that one has to define which infections to consider in the analysis. Serious bacterial infections occurred in $38 \%$ of the children, but minor infections occurred in almost $70 \%$ and viral infections occurred in about $38-40 \%$. So if you put them all together, almost everybody had an infection at some point. We could try to pull out the IVIG effective group for some definition of infections and look, but we have not done that yet.

Dr. Fischer: One thing that we found, and you have probably seen it too, is that it seems some of the children tend to have a majority of the infections, whereas others will have some infections, but there are really two different groups. That might be worth looking at.

Dr. Mofenson: That is a good idea.

Dr. Ballow: I have two questions, one for Dr. Mofenson, and one for either Dr. Fischer or Dr. Hill. Dr. Mofenson, concerning the metabolism of the IVIG, did you compare children who were hypogammaglobulinemic and those that are hypergammaglobulinemic? I wonder whether that is a variable.

Dr. Mofenson: I want to look at that; we have not as yet. The pharmacokinetics of IVIG in HIV-infected children is not pub- 
lished anywhere, and we did not do that study. We do have a serum bank with entry serum, which is frozen. One of the things I would propose to our group is that we look at the entry levels of gamma globulin in these children and try to look at time to infection, but it has not been done yet.

Dr. Ballow: My second question concerns several comments that were made about the incidence of pneumococcal infections. In my naive way of thinking about it, we can prophylax easily just with penicillin, but I want to ask the opsonic investigators whether that is sufficient to prevent pneumococcal infections without the presence of opsonic antibody and whether we need to use the IVIG even with penicillin prophylaxis.

Dr. Fischer: Penicillin prophylaxis has been effective in patients who have other immunologic defects. I would think penicillin prophylaxis would be an alternative. You are probably not going to cover all of the pneumococci with the IVIG; there are going to be capsular serotypes that you probably don't have antibody to.

Dr. Mofenson: But it will not cover viral infections.

Dr. Fischer: Penicillin will not. You're right about that. 